\title{
The African Union, African Economic Community and Africa's Regional Economic Communities: Untangling a Complex Web
}

\author{
Richard Frimpong Oppong*
}

\section{INTRODUCTION}

In 2007 and 2008, the African Union (AU) adopted two protocols that are significant for economic integration in Africa. These are the Protocol on the Relations between the African Union and the Regional Economic Communities [Protocol on Relations] ${ }^{1}$ and the Protocol on the Statute of the African Court of Justice and Human Rights [Protocol on the African Court of Justice]. ${ }^{2}$ The former aims at addressing a difficult problem with Africa's economic integration, which is, the existence of multiple regional economic integration organisations with overlapping memberships, and no clear principles of co-ordination among them. The latter establishes a court with jurisdiction over issues that potentially encompass those arising under the Treaty establishing the African Economic Community [AEC Treaty]. ${ }^{3}$ The AEC Treaty is the foundation of an attempt to create an economic community covering the whole of Africa - a continent with 53 sovereign states. If successful, the African Economic Community will be the largest economic integration organisation (in terms of membership) in the world.

The adoption of the Protocol on Relations and the Protocol on the African Court of Justice provides an auspicious moment to examine a fundamental question: what is the relationship between the AU, Africa's regional economic communities (RECs) and the African Economic Community (AEC)? This is a complex question, which has so far not received any systematic examination in the discourse on Africa's economic integration. ${ }^{4}$ Finding answers to the question and clarifying the relationship are important for the success of economic integration in Africa. This paper aims to put up this issue for serious discussion and research.

\section{THE AEC AND AFRICA'S RECs}

In 1994, the AEC Treaty entered into force. The treaty envisages the creation of an African Economic Community over a period of thirty four years using six defined stages of

\footnotetext{
* Lecturer in Law, Lancaster University Law School. LL.B., BL (Ghana) LL.M (Cantab) LL.M (Harvard).

${ }^{1} 17$ African Journal of International and Comparative Law (2009): 000. When it enters into force, this protocol will replace the Protocol on Relations between the African Economic Community and the Regional Economic Communities, 25 February 1998, reprinted in 10 African Journal of International and Comparative Law Afr. J. Int'l \& Comp. L. (1998) 157 [Protocol on the Relations between the AEC and RECs].
}

${ }^{2} 17$ African Journal of International and Comparative Law (2009) 000. When it enters into force, this protocol will replace the Protocol to the African Charter on Human and Peoples' Rights on the establishment of an African Court on Human and Peoples' Rights, 9 June 1998 and the Protocol of the Court of Justice of the African Union, 11 July 2003, 13 African Journal of International and Comparative Law (2005): 115.

${ }^{3}$ See Treaty establishing the African Economic Community, 3 June 1991, 30 International Legal Materials 1241 [AEC Treaty].

${ }^{4}$ Senghor's commentary on the processes leading to the formation of the AEC suggests that there were some discussions on this question. Indeed, he suggests that the relationship between the OAU and the AEC was a theme of special study by experts. Arguably, the existing legal framework does not suggest that the question was thoroughly addressed. See J. Senghor, 'The Treaty establishing the African Economic Community: An Introductory Essay', 1 African Yearbook of International Law (1993): 183. 
evolution. ${ }^{5}$ Rather than start from scratch, the AEC uses existing RECs as the building blocks of the African Economic Community. ${ }^{6}$ In other words, progress by the RECs is progress for the AEC and a step closer to the African Economic Community. In the words of article 88(1) of the AEC Treaty, the African Economic Community 'shall be established mainly through the co-ordination, harmonization and progressive integration of the activities of [RECs]'? The RECs are ultimately to merge or be absorbed ${ }^{8}$ to form the African Economic Community. This is a unique and quite complicated approach to economic integration. Usually, countries form economic communities - free trade areas, customs union, economic unions, or complete economic integration. Indeed, to date, it appears the only known case of a successful 'merger' of RECs was the merger of the European Community with the European Free Trade Area to form the European Economic Area. ${ }^{9}$ A more recent attempt is the Union of South American Nations ${ }^{10}$ which is a free trade zone that unites the Common Market of the Southern Cone and the Andean Community.

Remarkably, although the REC's are the building blocks of the African Economic Community, they are not members of AEC or parties to the AEC Treaty. It is the individual African states which are parties to the AEC Treaty and the treaties creating the RECs. Indeed, states are often parties to more than one REC. These raise complex questions. To what extent are the RECs bound by decisions of the AEC? Since the RECs, which have their own legal personality, are not parties to the AEC Treaty, what is the legal basis for assuming that they will merge and form the African Economic Community? Indeed, it is difficult to predict whether the RECs would willingly merge with the AEC. One may also query whether the AEC has the will or legitimacy to impose its vision of an African Economic Community on the RECs. ${ }^{11}$ If they were to merge and form the African Economic Community, what will be

\footnotetext{
${ }^{5}$ In a sense, the African Economic Community both is and is to be! Understandably, this may sound confusing to a reader. In this note the 'AEC' is used to refer to the current organization irrespective of the stage in its development, and reference to the ultimate stage of the AEC is written in full as 'the African Economic Community'.

${ }^{6}$ In 2006, the Assembly of Heads of State and Government of the African Union suspended, until further notice, the recognition of new RECs with the exception of the following eight: Economic Community of West African States (ECOWAS); Common Market for Eastern and Southern Africa (COMESA); East African Community (EAC); Economic Community of Central African States (ECCAS); Southern African Development Community (SADC); Inter-Governmental Authority for Development (IGAD); Arab Maghreb Union (AMU) and; Economic Community of Sahelo-Saharian States (CENSAD). See African Union, Decision on the Moratorium on the Recognition of Regional Economic Communities, Assembly/AU/ Dec.112 (VII), 2006. [RECs Moratorium Decision].

${ }^{7}$ Article 3 of the Constitutive Act of the African Union, 11 July 2000, 13 African Journal of International and Comparative Law (2005): 25, also underscores the need to 'coordinate and harmonize the policies between existing and future Regional Economic Communities for the gradual attainment of the objectives of the [African] Union'. Indeed, this is described as an 'objective' of the Union. It is worth noting that under article 88(2) of the AEC Treaty, it was the AEC (not the Organization of African Unity [now African Union] that was entrusted with the co-ordination, harmonisation and evaluation of the activities of existing and future regional economic communities.

${ }^{8}$ Protocol on Relations, supra note 1 art. 5(1)(d).

${ }^{9}$ See K. Riechenberg, 'The Merger of Trading Blocks and the Creation of the European Economic Area: Legal and Judicial Issues', 4 Tulane Journal of International and Comparative Law (1995): 63.

${ }^{10}$ It consists of Argentina, Bolivia, Brazil, Chile, Colombia, Ecuador, Guyana, Paraguay, Peru, Suriname, Uruguay and Venezuela. The treaty establishing the Union was signed on 23 May 2008.

${ }^{11}$ Equally important will be the AEC's ability to finance the cost of the merger.
} 
the legal status of the REC's after the merger? ${ }^{12}$ None of these questions is effectively addressed in the Protocol on Relations.

Nor do the founding treaties of the RECs shed any brighter light on these issues. For example, the Treaty establishing the Common Market for Eastern and Southern Africa ${ }^{13}$ envisages the conversion of COMESA into an organic entity of the African Economic Community. ${ }^{14}$ This appears to suggest that COMESA does not envision the formation of the African Economic Community as its demise. However, the treaty provides that the Authority of Heads of State and Government may, on the recommendation of the Council of Ministers, terminate the operations of the COMESA. ${ }^{15}$ This suggests that a legal mandate exists for bringing COMESA to an end, if that is what will be needed after the formation of the African Economic Community. Neither the Revised Treaty establishing the Economic Community of West African State ${ }^{16}$ nor the Treaty establishing the East African Community ${ }^{17}$ contains any provision directly relevant to their status after the formation of the African Economic Community.

The RECs' treaties were drafted after the AEC Treaty. Therefore, one would have expected that they will address the issues of their relations with the AEC and of their status after the formation of the African Economic Community more comprehensively and, perhaps, uniformly. As organizations created by treaties, the state parties retain an inherent right to terminate the treaty ${ }^{18}$ if that is what will be needed for them to form the African Economic Community. As the RECs are progressing further on the stages of integration, the merger issue should engage the AEC's attention.

Indeed, I would suggest that negotiating a merger protocol should start now given the complexity and size of the undertaking. It should address inter alia issues relating to: the post-merger legal status of the RECs; their assets and liabilities after the merger; whether the merger is compulsory or voluntary and, if compulsory, how that is going to be enforced; when the merger is to occur (simultaneously for all the RECs or incrementally after each reaches the needed stage of integration); the status of their personnel; and the status of active

\footnotetext{
${ }^{12}$ The United Nations Economic Commission for Africa (UNECA) conceives the future relationship between the AEC and the RECs in this way: After the [RECs] have achieved a customs union and a common market, they will merge to form the African Common Market, and the full-fledged African Economic Community intervention will follow. The African Economic Community will take the lead on dealing with member countries, and the functions and structures of the [RECs] will be revised to serve as its implementation arms. See UNECA, Assessing Regional Integration in Africa II: Rationalizing Regional Economic Communities, (2004), p. 94.

${ }^{13}$ Treaty establishing the Common Market for Eastern and Southern Africa, 5 November 1993, 33 International Legal Materials 1067 [COMESA Treaty].

${ }^{14}$ Ibid. art. 178(1)(c).

${ }^{15}$ Ibid. art. 192(1).

16 See Revised Treaty establishing the Economic Community of West African States, 24 July, 1993,35 International Legal Materials 660, (1996) 8 African Journal of International and Comparative Law 187 [ECOWAS Treaty]. Article 2(1) provides that the member states have decided that ECOWAS shall ultimately be the sole economic community in the region for the purpose of economic integration and the realization of the objectives of the African Economic Community.

${ }^{17}$ Treaty for the establishment of the East African Community, 30 November 1999, 2144 United Nations Treaty Series I-37437 [EAC Treaty]. In its preamble, the member states affirmed their desire for a wider unity of Africa and regarded the Community as a step towards the achievement of the objectives of the AEC Treaty.

${ }^{18}$ Vienna Convention on the Law of Treaties, 23 May 1969, 1155 United Nations Treaty Series 331, art. 54(b).
} 
RECs, such as the Southern African Customs Union, which have not been recognized as building blocks of the AEC.

The anticipated merger of the RECs raises other issues. Some, like the EAC, are at an advanced stage of development. It is difficult to predict whether they would willingly merge with their less progressive counterparts such as the Inter-Governmental Authority on Development. It is also arguable whether a merger of the RECs will be supported by interest groups within the RECs. Public choice theorists characterise international organisations as bureaucracies that are more responsive to the demands of organised interest groups, including their staff. As Vaubel notes, 'like all bureaucracies, international organizations fight for their survival and for more powers and resources. Thus, it is more difficult to abolish an international organization than to establish it, or to reduce its powers and resources than to increase them'. ${ }^{19}$ Indeed, already, an appreciable number of staff cases have appeared before the courts set up by the various RECs, an evidence of people trying to protect their 'turf' ${ }^{20}$ The number of staff cases, and the tenacity with which they appear to have been pursued, lend some credence to Rasul's thesis that economic integration has become a job generating venture for Africa's educated elite, ${ }^{21}$ and raise the prospect of obstructionist litigation before and during the merger.

Additionally, the RECs are legal systems in their own right. Unlike the AEC, they are expressly endowed with separate legal personality. ${ }^{22}$ Accordingly, even before the merger, there is the need to structure and manage the relations between the AEC and the RECs' legal systems as well as among the RECs. The Protocol on Relations does not go far in addressing these complicated relational issues

Effectively and boldly addressing the problems resulting from multiple memberships and the troubling relational issues between the AEC and the RECs, and among the RECs, will require legal imagination, economic thought, and strong institutional and political will. There is the urgent need for the AEC to actively rationalise the relations among the RECs and between the RECs and itself. ${ }^{23}$ This is important for the development of the African Economic Community. The 2006 AU moratorium on the establishment and recognition of

19 Ronald Vaubel, International Organization, in Charles K Rowley \& Friedrich Schneider eds., The Encyclopedia of Public Choice, Springer (2003), p. 319.

${ }^{20}$ See e.g. Muleya v. Common Market for Eastern and Southern Africa (No. 3) [2004] 1 East Afr. L. R. 173; Muleya v. Common Market for Eastern and Southern Africa (No. 2) [2003] 2 East Afr. L. R. 623; Muleya v. Common Market for Eastern and Southern Africa [2003] 1 East Afr. L. R. 173; Ogang v. Eastern and Southern African Trade and Development Bank [2003] 1 East Afr. L. R. 217; Eastern and Southern African Trade and Development Bank v. Ogang [2001] 1 East Afr. L. R. 46; Eastern and Southern African Trade and Development Bank v. Ogang (No. 2) [2002] 1 East Afr. L. R. 54; Tokunbo Lijadu Oyemade v. Executive Secretary of ECOWAS, Suit No ECW/CCJ/APP/01/04, (ECOWAS Court of Justice, 2006, unreported); Executive Secretary of ECOWAS v. Tokunbo Lijadu Oyemade, Suit No ECW/CCJ/APP/01/05, (ECOWAS Court of Justice, 2006, unreported); Executive Secretary of ECOWAS v. Tokunbo Lijadu Oyemade, Suit No ECW/CCJ/APP/04/06, (ECOWAS Court of Justice, 2006);

${ }^{21}$ Rasul Shams, 'The Drive towards Economic Integration in Africa', (Hamburg Inst. Of Int'l Econ., Discussion Paper No. 316, 2005): 6-7.

${ }^{22}$ See e.g. COMESA Treaty, supra note 13 art. 186(1); EAC Treaty, supra note 17 art. 138(1); ECOWAS Treaty, supra note 16 art. 88(1).

${ }^{23}$ See UNECA, Assessing Regional Integration in Africa II: Rationalizing Regional Economic Communities, (2004). 
more RECs was an important first step. ${ }^{24}$ So far, it has been heeded. I suggest that another important step will be for the AEC to adopt a protocol founded on a 'one country-one community membership' of the eight AU recognised RECs principle. With the help of national institutions and commissioned experts, countries should be guided to decide based on predominately economic criteria, which RECs best suits their needs taking into account the fact that the ultimate realization of the vision of an African Economic Community may help address some of their needs. This should not be viewed as an inappropriate infringement on state sovereignty, but as a measure needed for effectively pooling state sovereignty for a common good.

Indeed, the legal foundation for such as protocol can be sought in article 5(1) of the AEC Treaty. In it, member states undertook to 'create favourable conditions for the development of the Community and the attainment of its objectives, particularly by harmonising their strategies and policies', and to 'refrain from any unilateral action that may hinder the attainment of the said objectives'. I argue that the unilateral decision of AEC member states to be members of multiple RECs creates unfavourable conditions for the development of the AEC.

Admittedly, getting support for and enforcing this protocol will be difficult. It will be the ultimate test not only of the enforcement powers of the AEC, but also of member states' commitment to the realisation of its vision beyond their political rhetoric of support. Noncomplying states should be threatened with expulsion and ultimately expelled from the AEC and all but one of the RECs to which they are members. ${ }^{25}$ I dare say that the vision of an African Economic Community should not be founded on the ideal of all African countries as members. The European Community does not consist of all states in Europe. The North American Free Trade Agreement covers less than all countries on the North American continent. And the World Trade Organization comprises less than all the countries of the world. There is no legitimate reason why an African Economic Community cannot consist of something less than all of Africa! For a continent consisting of 53 state, a few of them dysfunctional, collapsed or collapsing, and many with different levels of socio-economic, legal and political development, the pursuit of this ideal will delay, indeed, thwart the timely realization of a noble economic vision.

Writing in the context of the collapse of the OAU, Professor Kufuor perceptively observed that 'unrestricted access in the form of virtually no entry requirements led to the tragedy of the regional commons, the degrading of the OAU as an organization of any value'. ${ }^{26}$ Won't the stature, integrity and effectiveness of the OAU/AU have been enhanced if it consisted of say twenty democratic, human rights respecting, socially and economically developed states which extend the benefits of the organisation to non-members on defined conditions? Like Professor Kufuor, I argued here that Africa's economic integration is being devalued, delayed and diluted due to the fact that countries are able to sign up at will without strict prior defined and continuous commitments to implementation. An African Economic Community which consists of a few African states can extend through conditioned agreements the benefits of integration to other countries that need not necessary be its

\footnotetext{
${ }^{24}$ See RECs Moratorium Decision, supra note 6.

${ }^{25}$ These countries can still be members AU, the 'political' organization.

${ }^{26}$ K. O. Kufuor, 'The Collapse of the Organization of African Unity: Lessons from Economics and History', 49 Journal of African Law (2005): 132 at 133.
} 
members. ${ }^{27}$ The expansion of economic space need not be a concomitant of the expansion of institutional space.

The 'one country-one community membership' principle should be combined with the full integration of the RECs into the legal framework of the AEC by making them members. It is unfortunate that neither the Protocol of Relations between the African Economic Community and the Regional Economic Communities, nor the new Protocol of Relations does this. ${ }^{28}$ For the RECs to become members of the AEC there should be an amendment to the AEC Treaty. Currently, the AEC Treaty does not have a membership provision or criterion, but it appears to assume all African state as potential members. ${ }^{29}$ By becoming fully signed up members of the AEC, the RECs will be bound by all AEC laws, including laws which aim at rationalizing and co-ordinating their activities. They will become subject to AEC enforcement processes and active and interested participants in its decision making process. This will help in the elimination or at least minimise of potential conflict of laws, policies and jurisdiction.

\section{III.THE AU AND THE AEC}

As if the above was not complex enough, another leg must be added to this bizarre web of legal relations on the path to Africa's economic integration. This is the OAU (now AU) leg. Africans have long aspired to be politically united. The OAU was a first step towards this goal. However, economic integration and political unification are two distinct ideas. These two ideas should not be convoluted. They need not be pursued together. Indeed, the former is definitely achievable without the latter. In my opinion, a principal problem with economic integration in Africa is the non-realisation of this truth. ${ }^{30}$ In Africa, there has been a convolution of these two ideas. This convolution of ideas has led to an inappropriate structuring and fusion of institutions, which ultimately ill-serve the objectives of economic integration.

For the AEC, the problem of mixing the economic with the political began when its founding treaty declared in article 98(1) that 'the Community shall form an integral part of the [Organisation of African Unity]'. ${ }^{31}$ Article 99 went on to declare that the treaty and protocols adopted under it shall form an integral part of the OAU Charter. With these provisions, it appears the drafters thought it unnecessary to expressly give the AEC a separate legal personality; accordingly, the treaty is silent on this issue. ${ }^{32}$ What was meant by 'an

\footnotetext{
${ }^{27}$ An example of this may be the relationship between the European Community and Turkey.

${ }^{28}$ Both instruments are signed by the RECs, but this does not make them members of the AEC.

${ }^{29}$ Compare article 3 of the EAC Treaty, supra note 17, which sets out matters to be taking into account in considering a membership application from 'a foreign country'.

${ }^{30}$ It appears reality dawned on Africa leaders when they declared as one of the steps towards the creation of the Union Government of Africa the following: To rationalize and strengthen the [RECs], and harmonize their activities, ... so as to lead to the creation of an African Common Market, through the stages set in the Treaty Establishing the African Economic Community (Abuja Treaty), with a reviewed and shorter timeframe to be agreed upon in order to accelerate the economic and, where possible, political integration. See African Union, Accra Declaration, 3 July 2007, para. 2(a) [emphasis added].

${ }^{31}$ AEC Treaty, supra note 3.

${ }^{32}$ However, in his capacity as the legal representative of the Community, the Secretary-General is given power to, on behalf of the Community, enter into contracts and be a party to judicial and other legal proceedings. See AEC Treaty, ibid. art. 98(2).
} 
integral part' was not defined. But the immediate effect of these provisions was that the institutions or organs of the OAU were co-opted to perform the functions of the institutions established by the AEC Treaty. There appears to have been no careful thought as to whether, as then structured, the OAU institutions suited the needs of economic integration. The Constitutive Act of the African Union ${ }^{33}$ did not address this problem. After passing references to the African Economic Community in the preamble, it simply provided that the 'Act shall take precedence over and supersede any inconsistent or contrary provisions of the [AEC Treaty]'.

Historically and comparatively, it is worth recalling that the Treaty for East African Cooperation $^{34}$ which established the East African Community had 'as an integral part of the Community ${ }^{35}$ the East African Common Market. However, unlike the situation with the AEC, the Treaty for East African Co-operation established at least two institutions devoted specifically to the common market, namely the Common Market Council and Common Market Tribunal. ${ }^{36}$ More recently, Professor Asante has decried the use of the organs of the OAU (now AU) as the basic organs of the AEC. ${ }^{37}$ These organs are ill-equipped to meet the challenges of integration. The effect of this fusion of institutions has been the loss of identity of the AEC. Indeed, as he graphically puts it, the AEC has no 'letterhead of its own', it 'has, in fact become just a division, albeit an important one, of a continental political institution'. ${ }^{38}$ In his view, which I endorse, 'the AEC surely requires distinct and separate institutional arrangements'. ${ }^{39}$ The African Court of Justice is, perhaps, the best example of the inappropriateness of the convolution of institutional roles.

The Court of Justice of the $\mathrm{AEC}^{40}$ was to be an important institution for the enforcement of AEC law. It was to be independent of all the other community institutions. Its mandate was to 'ensure the adherence to law in the interpretation and application of [the AEC Treaty] and shall decide on disputes submitted thereto pursuant to [the AEC Treaty]'. ${ }^{41}$ The detailed law regulating the court was to be set out in a protocol. But, it appears that this distinct court devoted to economic integration issues will never be established. Its functions will now be performed by the African Court of Justice and Human Rights [African Court of Justice]. ${ }^{42}$

\footnotetext{
${ }^{33}$ Constitutive Act of the African Union, supra note 7.

${ }^{34} 6$ June 1967, 6 International Legal Materials 932.

${ }^{35}$ Ibid. art. 1(1).

${ }^{36}$ Ibid. arts. 3, 30-31, 32-42.

${ }^{37}$ S.K.B. Asante, 'Towards an African Economic Community', in S.K.B. Asante (eds), Towards an African Economic Community, African Institute of South Africa (2001).

${ }^{38}$ Ibid. at 8-9 [emphasis added].

${ }^{39}$ Ibid. at 16.

40 See generally A.O. Obilade, 'The African Court of Justice: Jurisdictional, Procedural and Enforcement Problems', in M.A. Ajomo \& Omobolaji Adewale (eds), African Economic Community Treaty, Issues, Problems and Prospects, Nigerian Institute of Advanced Legal Studies (1993) 312.

${ }^{41}$ AEC Treaty, supra note 3 art. 18(2).

${ }^{42}$ Protocol on the Statute of the African Court of Justice and Human Rights (2008), available at www.africaunion.org/root/au/Documents/Treaties/treaties.htm (accessed 4 November 2009) [Protocol on the African Court of Justice]. Annexed to the protocol is the Statute of the African Court of Justice and Human Rights [Statute of the African Court of Justice]. The protocol is not yet in force. As at July 2009, only Libya had deposited its instrument of ratification.
} 
The African Court of Justice consists of sixteen judges who must all be nationals of states that are parties to the Protocol on the African Court of Justice. ${ }^{43}$

The subject matter jurisdiction of the African Court of Justice is broad. In theory, it covers potentially any international dispute arising between states which are parties to the Protocol of the African Court of Justice. The jurisdiction of the African Court of Justice, as outlined in article 28 of the Statute on the African Court of Justice, is wide enough to cover the AEC Treaty and any laws adopted by the AEC.

The strength of a court depends not only on its independence and subject matter but also it personal jurisdiction. Under article 29 of the Statute of the African Court of Justice, the following entities are entitled to submit cases to the court on 'any issue or dispute ${ }^{, 44}$ provided for in article 28: states that are parties to the Protocol of the African Court of Justice; the Assembly; the Parliament and other organs of the AU authorised by the Assembly; and a staff member of the AU. A state that is not party to the protocol may not submit a case to the African Court of Justice, ${ }^{45}$ the court has no jurisdiction to hear a dispute involving such a party. Equally, it does not appear that the RECs, the building blocks of the AEC, have standing before the court.

The fact that the court has no jurisdiction over states that are not parties to the protocol, even though they may be parties to the AEC Treaty, poses a challenge to judicial enforcement of the treaty. Surely, under traditional international law, states, as an attribute of their sovereignty cannot be dragged to an international tribunal without their consent. But, in the context of regional economic integration, ${ }^{46}$ this jurisdictional gap will not aid the uniform application and enforcement of community law within member states. In my opinion, this jurisdictional gap is a reflection of inattention to the importance of legal issues in integration. A foundation for instability is laid where uneven obligations, in terms of the enforcement and enforceability of community law, are imposed on member states. It is difficult to conceive of a stable and effective economic community where community law is not uniformly applicable within and enforceable against member states. Indeed, the very essence of integration is defeated; 'uniformity in the meaning of law is part of the constitutional glue that holds the Community together'. ${ }^{47}$

Individuals also have an important role to play in economic integration, not least in ensuring the implementation of community laws. For example, the COMESA, EAC, ECOWAS and SADC treaties provide fairly liberal rules on individuals' participation in the

\footnotetext{
${ }^{43}$ Statute of the African Court of Justice, ibid. art. 3(1).

${ }^{44}$ On human rights related disputes, the list of entities that can bring actions before the African Court of Justice to include: the African Commission on Human and Peoples' Rights; the African Committee of Experts on the Rights and Welfare of the Child; African Intergovernmental Organizations accredited to the Union or its organs; African National Human Rights Institutions; and, for states that specifically agree to this, individuals or relevant Non-Governmental Organizations accredited to the African Union or to its organs. See Statute of the African Court of Justice, supra note 42 art. 30.

${ }^{45}$ Statute of the African Court of Justice, supra note 42 art. 18.

46 Such a jurisdictional gap might work in a purely political context. For example, except with its express consent, the International Court of Justice has no jurisdiction over a states even if it is a member of members of the United Nations and, ipso facto, party to the Statute of the International Court of Justice. The case of the African Court of Justice represents an inappropriate extension to economic integration of an approach developed for and workable in a purely political context.
}

${ }^{47}$ S. Weatherill, Law and Integration in the European Union, Clarendon Press (1995), p. 135. 
communities' judicial processes. Indeed, to date, individuals have been responsible for almost the entire disputes settled by their respective courts. ${ }^{48}$ The Statute of the African Court of Justice adopts a radically different approach. Except for human rights claims, individuals have no standing before the African Court of Justice. On matters relating to the interpretation, enforcement and validity of AEC laws, individuals cannot bring an action in the African Court of Justice. A provision in the earlier Protocol on the Court of Justice of the African Union, ${ }^{49}$ which allowed individuals to access the court under conditions determined by the Assembly and with the consent of the state concerned, has been omitted from the Statute on the African Court of Justice. Accordingly, the African Court of Justice resembles the international adjudication regime category in Schneider's typology of dispute settlement systems. ${ }^{50}$ Such a regime is ill-suited for the level of integration envisaged under the AEC Treaty, although it may adequately serve the needs of the AU - the political organisation. ${ }^{51}$

The absence of locus standi for individuals restricts the number of potential disputes that may be brought to the African Court of Justice. It makes the dispute settlement process unavailable to some of the most important players in the integration process, including consumers, traders, corporate bodies, and investors. It fails to utilise a principal medium through which community-state relationship is strengthened in economic integration. A plausible solution, which is still more restricting compared to the standing rules of COMESA, EAC and ECOWAS courts, will be to allow individuals to litigate before the African Court of Justice with the special leave of the court, ${ }^{52}$ or after exhausting local remedies. Another option is to create a reference procedure between national courts and the African Court of Justice. This alternative will provide individuals with an indirect access to the court.

In general, governments are reluctant to submit to binding interstate dispute resolution processes. Indeed, of all the cases so far brought before the COMESA, EAC, ECOWAS and SADC courts only one involved inter-state parties. ${ }^{53}$ In the absence of individual standing, the African Court of Justice might be underused and may be consigned to 'abject inactivity

\footnotetext{
${ }^{48}$ See e.g. Mike Campbell Ltd. v. The Republic of Zimbabwe, SADC Tribunal Case No SADCT: 2/07, (SADC Tribunal, 2007 and 2008); Calist Andrew Mwatela v. East Africa Community, EACJ Reference No 1 of 2005 , (East Africa Court of Justice, 2006); East African Law Society v. Attorney General of Kenya, Application No. 9 of 2007, (East African Court of Justice, 2007); East African Law Society and others v. Attorney General of Kenya, Reference No. 3 of 2007, (East African Court of Justice, 2008); Peter Anyang' Nyongo v. A.G. of the Republic of Kenya [2008] 3 K.L.R. 397; Eastern and Southern African Trade and Development Bank v. Ogang [2001] East Afri. L.R. 46; Olajide Afolabi v. Federal Republic of Nigeria, 2004/ECW/CCJ/04, (ECOWAS Court of Justice, 2004).

${ }^{49}$ Supra note 2 art. 18.

50 A.K. Schneider, 'Getting Along: The Evolution of Dispute Resolution Regimes in International Trade Organizations’, 20 Michigan Journal of International Law (1998-1999): 679-733.

${ }^{51} \mathrm{Ibid}$. at 761 where she notes that the international adjudicatory regime is best used when the goals of integration are limited'.

${ }^{52}$ Revised Treaty of Chaguaramas Establishing the Caribbean Community including the CARICOM Single Market and Economy, 2001, art. 222, available at www.caricom.org/jsp/secretariat/legal_instruments.jsp?menu=secretariat (accessed 4 November 2009). This provision has been interpreted and applied by the Caribbean Court of Justice in Trinidad Cement Ltd. v. The State of the Co-operative Republic of Guyana [2009] C.C.J. 1 (OJ); Trinidad Cement Ltd. v. The Caribbean Community [2009] C.C.J. 2 (OJ). In both cases, the court granted the applicant leave to bring an action.

${ }^{53}$ See Eritrea v. Ethiopia [1999] LawAfrica L. R. 6.
} 
and irrelevance', ${ }^{54}$ as far as economic integration issues are concerned. One can only imagine what would have happened to the COMESA, ECOWAS and EAC courts if individuals did not have standing before them. Granting private right of action will ensure the use of the African Court of Justice, and prevent its descent into inactivity and irrelevance.

Arguably, the absence of individual rights of action reflects a desire of states to dominate the African Court of Justice, even if only indirectly, and cut off the court from any relations with those most affected by economic integration. The absence of individual standing is inconsistent with the position in other African regional economic treaties. It is recommended that any revisions of the Statute of the African Court of Justice should provide for individual standing either directly, with special leave of the court or after exhausting local remedies, or indirectly through reference from national courts. ${ }^{55}$

Perhaps, if the distinct identity of the AEC had been maintained and its economic integration agenda and the concomitant needs of the agenda held in focus, these shortfalls might have been avoided. As a court for the political organization, the AU, it is unproblematic; its structure and jurisdiction closely resemble the International Court of Justice of the United Nations. But, as a court which also has jurisdiction over economic integration issues, its structure and jurisdiction are highly inadequate. To my knowledge, it is the only court with jurisdiction over an economic integration agreement whose jurisdiction is not compulsory. A party to the AEC Treaty which has not ratified the Protocol of the African Court of Justice is not subject to the jurisdiction of the court. ${ }^{56}$ As has been argued above, this will seriously affect the application and enforcement of AEC law. Individuals and national courts, key players in the success of any economic integration agenda have no direct or indirect relations with the courts.

\section{CONCLUSION}

The relationship between the AU, AEC and Africa's RECs is complex. I attribute this to two factors. Firstly, there appears to be a lackadaisical approach to the legal aspects of the economic integration being undertaking under the aegis of the AEC. It does not appear that treaties and protocols are adopted with much careful thought on the complex legal issues involved in economic integration. It is the hope of this writer that the newly established African Union Commission on International $\mathrm{Law}^{57}$ will devote considerable space on its agenda to the legal aspects of economic integration on the continent. Secondly, there has been a convolution of the two distinct ideas namely economic integration and political unification. This has led to approaches to issues, including the establishment of institutions, that ill-serve

\footnotetext{
54 Tiyanjana Maluwa, 'The Peaceful Settlement of Disputes among African States, 1963-1983: Some Conceptual Issues and Practical Trends', 38 International and Comparative Law Quarterly (1989): 299 at 307.

${ }^{55}$ Initially, the ECOWAS Court of Justice did not have jurisdiction to hear cases from individuals. It was granted that jurisdiction through an amendment to its protocol. See Protocol A/P.1/1/91 on the Economic Community of West African States Court of Justice (as amended Supplementary Protocol A/SP.1/11/04). See also Olajide Afolabi v Federal Republic of Nigeria, supra note 48 in which the court dismissed the application for lack of standing.

${ }^{56}$ Statute of the African Court of Justice, supra note 42 art. 29(2).

57 Statute of African Union Commission on International Law (2009), available at http://www.africaunion.org/root/au/Documents/Treaties/text/STATUTE\%200F\%20THE\%20AUCIL-Adopted\%20$\% 20 \mathrm{Feb} \% 202009$.pdf (accessed on 4 November 2009).
} 
the needs of integration. African lawyers and legal academics are culpable in this state of affairs. The extent to which both groups have taken interest the economic integration agenda is doubtful. ${ }^{58}$ This fact is reflected in the small number of books, journal and articles dealing with the legal aspects of economic integration in Africa. ${ }^{59}$ If Africa's economic integration is to succeed, its legal aspects has to be taken more seriously and it should be clearly divorced from the political unification agenda. Admittedly, the socio-economic and political challenges that bedevil Africa's economic integration are enormous and real. However, in my opinion even if all these challenges were to disappear, there are so much in the realm of law which, if unaddressed, will still hinder the success and effectiveness of economic integration in Africa.

58 See generally Simon E. Kulusika, 'The Lawyer and the Challenges of Economic Integration' (2000) 32 Zambia L.J. 20.

${ }^{59}$ In this regard, an important initiative by the AU worth noting is the publication by the AU Commission of the African Integration Review. This is a peer reviewed journal dedicated to economic integration in Africa. See http://www.africa-union.org/root/ua/Newsletter/EA/Contenueng.htm. 